\title{
Sustainable Tourism in APEC: A Region with UNWTO Members and Non-members
}

\author{
Cuauhtemoc Ramirez ${ }^{1}$ \\ ${ }^{1}$ Faculty of Tourism, University of Colima, Mexico \\ Correspondence: Cuauhtemoc Ramirez, Faculty of Tourism, University of Colima, Mexico. E-mail: \\ cuauhtemoc_ramirez@ucol.mx
}

Received: February 19, 2018

Accepted: March 14, 2018

Online Published: May 2, 2018

doi:10.5539/jsd.v11n3p1

URL: https://doi.org/10.5539/jsd.v11n3p1

\begin{abstract}
Tourism has become a source of income, employment and economic growth for the country members of the Asia-Pacific Economic Cooperation (APEC). This paper analyses tourism as a regional economic activity that interacts with the environment, with positive effects such as improving economic competitiveness; and negative effects such as overcrowding and poor management that can destroy the touristic asset on which the activity depends. These issues put the membership of the World Tourism Organization (WTO) of some APEC economies at stake, as well as the future of their local, regional and global economic and tourism competitiveness.
\end{abstract}

\section{Introduction}

Concerns about natural and social resources have generated a series of debates about tourism and its relationship with the environment. Tourism, as a productive activity, is unquestionably beneficial to the extent that it generates employment, regulates labour migration, improves the cultural level of the population, and stimulates people to look after the environment (Vilches and Gil, 2003). However, tourism is also considerably destructive if not handled properly, as it can wipe out the wealth of the natural, social or cultural assets of any country or region. This reality, and the imminent risk of deterioration in resources or the increase of economic activities that are not environmentally friendly, have led to a strong international, national and local movement interested in turning traditional practices into sustainable uses.

Other researchers in the field of tourism have classified it from an economic perspective, based on the benefits resulting from it. By its own nature, tourism has become a complex phenomenon of political, economic, social, cultural, educational, biophysical, ecological and aesthetic dimensions. In the book Tourism, Planning, Management and Prospects by McIntosh and Shaghikant (1987), numerous opportunities and possibilities are outlined, as well as potential conflicts, aspirations and desires of the host or local communities.

Alday and Ara (2012) consider tourism an important economic activity, in part due to its contribution to the generation of wealth and employment, and partly because of its significant drag on other sectors, which gives it a strategic character of the first magnitude. In another perspective and time period, Korstanje (2008) values that due to the large amount of voluntary human displacements, tourism must be studied by human sciences and by its impacts on the economy. Similarly, for its impact on the environment, tourism must be analyzed by the geographical, biological and environmental sciences; for its social impact, it must be studied by Sociology; and for its cultural impact by Anthropology. Likewise, behavioral issues and visitor-host relationships require studies using Social Psychology.

In addition, tourism today has a positive effect in the development of infrastructure and public services. Similarly, its contribution to social convergence should not be overlooked, as the free circulation of tourists brings the exchange of traditions and cultures, favoring the rapprochement of people (Hall, 2013).

For the Asia-Pacific Economic Cooperation (APEC) bloc, tourism is one of the most important economic activities. This is why priority is given to assessing its development and durability (Chavez, Zamora \& Torres, 2015).

The term "development in sustainability" is relevant to preserve the environment being visited and to increase the tourist competitiveness without jeopardizing the durability of the economic asset. Since its inception, each economy has set the parameters to develop its tourism in a good way and increase its competitiveness. Although 
some regions have opted to join the World Tourism Organization (WTO) while others chose to build their own development schemes, they must all be part of regional meetings that, as a result of global economic growth and the need for tourism preservation, seek to strengthen the APEC region and its future development.

\section{Methodology}

The tourism sector generates multiple impacts on the economy, society and the environment. In this context, this paper tries to assess why some countries have opted not to be part of the WTO and to define their own parameters of tourism development, and how APEC has achieved sustainable development.

The paper begins by constructing an analysis with different perspectives that relate the conceptualization of tourism, sustainability and competitiveness over time, which allows valuing various scenarios that have arisen historically after the conceptual analysis, the research goes into the valorization of WTO and its importance since its creation, not only in terms of economic results or number of visitors but also on whether the expenses of each tourist have increased.

The research encompasses some historical data that promote tourism sustainability in APEC and how many of its member economies have been benefited. However, the disparity in the membership of the WTO creates an exciting analysis that gives meaning to the present research.

\section{WTO Impacts and Its Development Paradigm}

UNWTO states that tourism has become the most important economic activity in the world, in addition to being one of the industries that register the highest growth. According to UNWTO (2016), between 1950 and 2015 the number of international tourist trips increased from 25 million to slightly more than one billion users, representing an annual growth rate of between 5\% and 7\%. Since 1995, UNWTO considers that the main characteristic of this industry is that, unlike production or services, tourism managers transport individuals to explore the natural features, cultural attractions and styles of a tourist destination.

In 1993, the APEC Tourism Working Group on Sustainable Tourism Indicators focused on the need to create boundaries and indicators that would assess the continuity of local and national government and businesses, considering the use and impact of tourism on the natural and cultural sector in which it operates. TWG presented a report closely associated with the importance of the long-term care of the environment, detecting problematic areas, as well as the need to raise awareness about changes to the activity growth, such as sensitivity of natural and cultural areas, among other aspects.

This theme strengthened within the WTO. In 1995 an innovative research was developed which established a system to measure the environmental health of destinations, with the goal of making tourism more sustainable. Furthermore, the research provided environmental indicators that allowed the formation of an early warning system to alert the authorities about possible detriments of the tourism asset. The research used ten essential environmental indicators and a series of specific gauges for tourist destinations in coastal areas, mountainous regions, traditional communities and small islands as pilot tests.

The topic of sustainable tourism began to expand within the WTO and its substantial fluctuation with positive results. Figure 1 shows the number of arrivals of international tourists and the income that tourism generated between 1995 and 2015. It also shows the annual constant increase of both figures, and that an increase in income was favored over total number of arrivals since 2008, aspect which some APEC economies are still unable to influence, by choosing not to overcrowd sites, and instead to set higher prices that have a positive impact on natural and socio-cultural resources. 


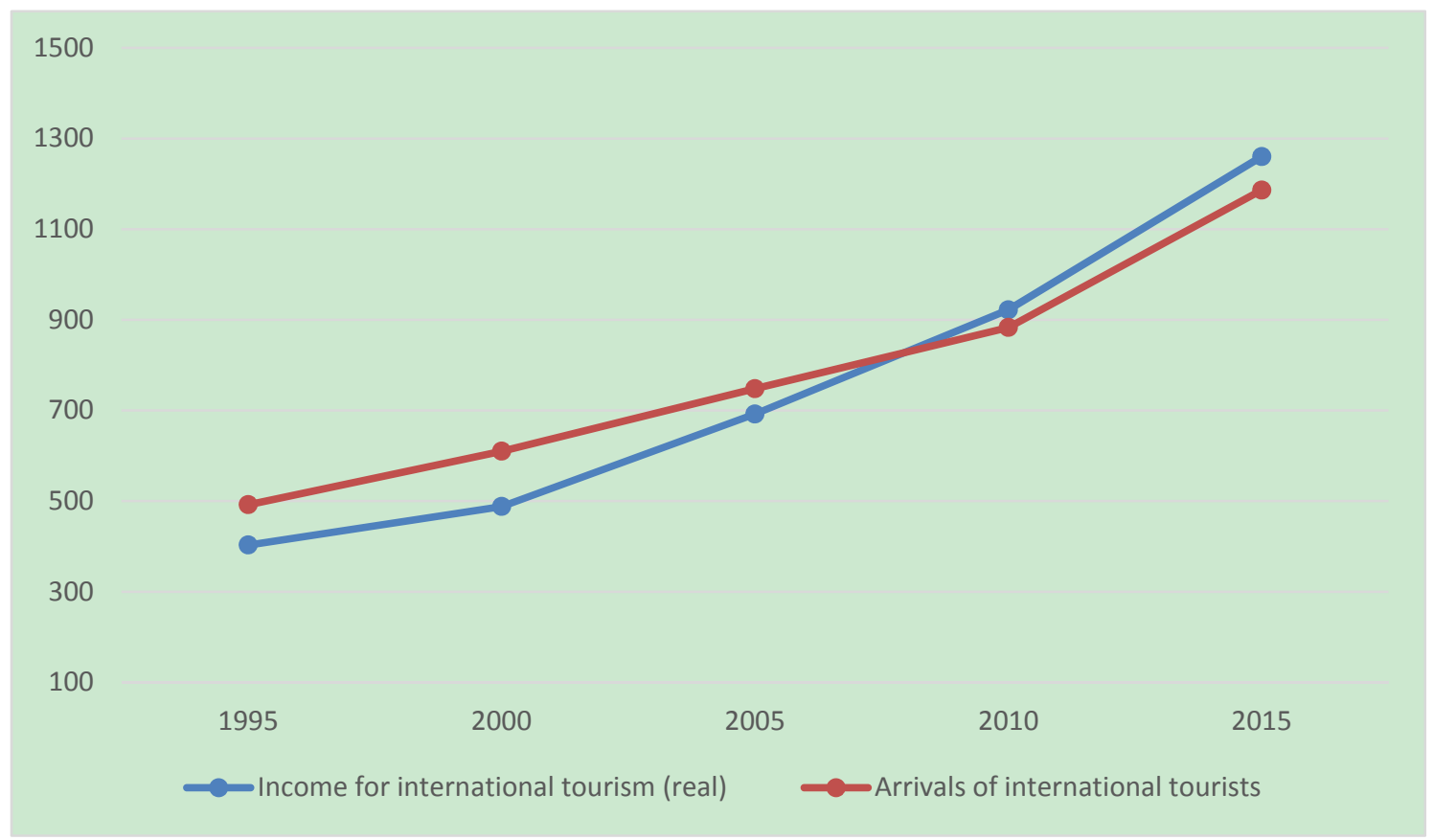

Figure 1. Tourism Receiver 2015

Source: World Tourism Organization (UNWTO).

\section{Tourism and Sustainable Growth in APEC}

As opposed to UNWTO, APEC, reflects a substantial increase in tourism activities and their development. From 2010 to 2017, APEC members experienced a growth in tourism revenues of $25 \%$, which surpasses trends in other sectors such as the automotive or oil industry worldwide (Ibáñes, 2016). Ibáñes also indicates that by 2015, the level of tourism competitiveness represented by the economies of this organization ranged from 4 to 80 at the global level, and that only 10 of the 19 APEC economies that were evaluated by the World Economic Forum (WEF) improved their level of competitiveness.

Based on the above, Cardoso (2007) reports that sustainable tourism in APEC has evolved regarding its conceptualization, without neglecting the three fundamental principles of economic, environmental and socio-cultural sustainability.

Since its creation, APEC has recognized the economic importance of sustainable tourism for its capacity to generate jobs, promote investment and sustainable development. In 1991, APEC formed the Tourism Working Group (TWG), whose work was guided by a document on tourism in APEC that was approved by the First Tourism Ministerial Meeting in South Korea in the year 2000.

By 2002, this document recognized the vital contribution of tourism to improving the economic, cultural and social environment of APEC member economies, and sets four key objectives: 1). Remove impediments to tourism-related business and investment (Thailand); 2. Increase visitor mobility and demand for tourism-related goods and services (Indonesia); 3. Achieve sustainable management of the effects of tourism (New Zealand) and 4. To promote understanding of travel and tourism as a vehicle for economic and social development (Australia). (APEC, 2002)

Since that year, APEC founded the International Center for Sustainable Study and, within it, the TWG, which sought to provide information and assistance to APEC economies and destinations to improve tourism sustainability throughout the region. At the same time, an infrastructure for tourism management called Total Tourism Management (TTM) was developed, which recognizes the benefits and the economic, environmental, social and cultural opportunities of APEC tourism activities based on certain objectives of a tourism-sustainable nature. The creation of TWG and TTM denotes the importance generated by the tourism economy and its preservation.

The work by the APEC TWG positioned itself as the most essential technical input for the successful realization of the agenda of the Ministerial Meetings of Tourism, which has approved important initiatives that reaffirm the 
absolute priority of tourism as an economic activity in the Asia-Pacific region. However, tourism often undermines the natural and socio-cultural resources of sites, which is why, concerned about this, in 2002 the International Center for Sustainable Tourism (AICST) was created, founded by the Tourism Working Group and the Ministers of Tourism of the 21 APEC economies. The role of the AICST is to provide information and assistance to APEC economies and destinations to improve the sustainability of tourism throughout the region.

In conclusion, we can observe that over time, UNWTO and APEC alike, have gone from valuing a traditional tourism approach to carrying out sustainable practices that in the future will force us to look for the conservation of the tourist asset based on its three dimensions of development.

\section{Discussions and Results of UNWTO and APEC in the Context of Tourism Competitiveness}

Although APEC was working on the basis of ministerial meetings on sustainable tourism since 2002, it was not until 2004 that the UNWTO announced its Guidebook of Indicators of Sustainable Development for Tourism Destinations (Note 1), where it seeks to achieve a process of planning and management of the tourist sites that are part of this organization, achieving an adequate decision making regarding the sustainable development of tourism.

Since then, this guide has served as the primary information facilitator that helps, through case studies, to circumscribe problems in sites and evaluate tourism proposals by WTO members with similar sites. Some researchers, such as Quiroga (2007), consider that for APEC, the planning and management instruments and indicators have increased with the progressive social, institutional and political awareness of sustainability. Others, such as Elliot (2014), identified in UNWTO the concern to find a balance between growth in tourism development and environmental preservation.

Table 1 shows the APEC economies according to their levels of competitiveness in travel and tourism (World Economic Forum, 2017) and lists those who belong to UNWTO.

Table 1. Indicators of tourism competitiveness in APEC economies

\begin{tabular}{|c|c|c|c|}
\hline Global Rank & Country / Economy & Score & Global change since 2015 \\
\hline 4 & Japan & 5.26 & 5 \\
\hline 6 & United States & 5.12 & -2 \\
\hline 7 & Australia & 5.10 & 0 \\
\hline 9 & Canada & 4.97 & 1 \\
\hline 11 & Hong Kong SAR & 4.86 & 2 \\
\hline 13 & Singapore & 4.85 & -2 \\
\hline 15 & China & 4.72 & 2 \\
\hline 16 & New Zealand & 4.68 & 0 \\
\hline 19 & Korea Republic & 4.57 & 10 \\
\hline 22 & Mexico & 4.54 & 8 \\
\hline 26 & Malaysia & 4.50 & -1 \\
\hline 30 & Taiwan, China & 4.47 & 2 \\
\hline 34 & Thailand & 4.38 & 1 \\
\hline 42 & Indonesia & 4.16 & 8 \\
\hline 43 & Russian Federation & 4.15 & 2 \\
\hline 48 & Chile & 4.06 & 3 \\
\hline 51 & Peru & 4.04 & 7 \\
\hline 67 & Vietnam & 3.78 & 8 \\
\hline 79 & Phillippines & 3.60 & -5 \\
\hline- & *Papua New Guinea & - & \\
\hline- & *Brunei Darussalam & - & \\
\hline
\end{tabular}


It is worth noting that of the eight best-positioned economies, only two are active members of the UNWTO, and combining this with the fact that the economies that have chosen not to be part of this organization are first world countries, raises doubts as to whether this organization truly works in an adequate way in favor of tourism's new needs and its preservation, resulting in the need for some economies to pose individual challenges in their way of developing this economic activity.

According to Manning (2004), non-UNWTO countries are those that indirectly dissociate the government as the main tourism in the most important sites, considering that the real tourism administration is carried out by provinces and states. Canada and the United States, for example, do not have any form of ministry or tourism secretariat at the national level. Australian states have powerful sustainable tourism units in specific areas such as their coasts, which typifies how tourism power is governed more by independent than government agencies, resulting in a lack of need to partner with organizations such as UNWTO.

Currently, WTO has linked different programs such as the International Network of Sustainable Tourism Observatories (INSTO); a network of tourist observatories that monitor the economic, environmental and social impact of tourism. China already has eight Sustainable Tourism Observatories, Japan has two, and these countries have revitalized the way in which the competitiveness of the tourist destination is developed, positioning Japan, for example, as the most competitive economy of APEC and member of WTO.

According to the World Economic Forum (2017) and Coccossis and Mexa (2017), for non-UNWTO organizations, true leadership comes from individual and university consultants who study specific ways of managing mass tourism based on development trends and long-term projections.

Some economies have decided not to be part of WTO, on the one hand due to the overexploitation of the natural resources that the visitation provokes and the bad management in its sustainable development (Arias, 2011); and on the other hand, due to new generations being more aware of the need to link tourism with environmental and socio-cultural conservation. One aspect to consider in this regard is that the UNWTO guide to sustainable tourism indicators has not been updated since 2004, resulting in some problems such as tourismphobia and uncontrolled overcrowding. However, Manning (2004) mentions that a network of 62 specialists in 23 countries was established on the Guidebook that contribute to leadership work. Governments began using the Guidebook a few years later and this served as a watershed to bring more sustainable tourism closer to the governments of most countries.

The APEC most competitive countries in terms of tourism sustainability (2015) are listed in Table 2, from which it can be estimated that most of the best-evaluated countries do not belong to UNWTO, leading to believ that the creation of models outside the World Tourism Organization has resulted in successful and more competitive indicators. 
Table 2. Tourism sustainability indicators in APEC economies

\begin{tabular}{|c|c|c|c|c|c|c|}
\hline \multirow[b]{2}{*}{ Country/Economy } & \multicolumn{2}{|c|}{$\begin{array}{c}\text { ICG } \\
2014-2015\end{array}$} & \multicolumn{2}{|c|}{$\begin{array}{l}\text { Social sustainability } \\
\text { adjustment ICG } \dagger\end{array}$} & \multicolumn{2}{|c|}{$\begin{array}{c}\text { Environmental sustainability } \\
\text { adjustment ICG } \neq\end{array}$} \\
\hline & Rank* & Score & Value & Direction & Value & Direction \\
\hline New Zealand & 4 & 5.93 & 5.94 & $\pi$ & 6.04 & $\Uparrow$ \\
\hline Singapore & 5 & 5.87 & 6.23 & $\Uparrow$ & 6.38 & $\Uparrow$ \\
\hline Malaysia & 7 & 5.76 & 5.59 & 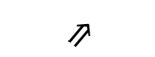 & 4.86 & $\nabla$ \\
\hline Hong-Kong SAR & 27 & 5.04 & 5.86 & $\pi$ & 5.76 & $\pi$ \\
\hline Australia & 29 & 5.02 & 5.8 & $\pi$ & 5.54 & $\pi$ \\
\hline United States & 34 & 5.00 & 5.97 & $\gg$ & 5.24 & $\nabla$ \\
\hline Canada & 37 & 4.94 & 5.95 & $\pi$ & 5.51 & $\pi$ \\
\hline Japan 욤 & 41 & 4.91 & 6.29 & $\pi$ & 5.83 & $\pi$ \\
\hline Peru & 49 & 4.82 & 3.99 & $\nabla$ & 4.02 & $\nabla$ \\
\hline Taiwan, China & 53 & 4.74 & 4.55 & $\Rightarrow$ & 4.48 & $\Rightarrow$ \\
\hline Phillippines 언 & 56 & 4.71 & 4.26 & $\Rightarrow$ & 4.25 & $\Rightarrow$ \\
\hline Indonesia 에 & 57 & 4.67 & 4.31 & $\nabla$ & 4.26 & $\nabla$ \\
\hline China 동 & 58 & 4.63 & 4.96 & $\Rightarrow$ & 4.28 & $\nabla$ \\
\hline Mexico 해 & 60 & 4.60 & 4.2 & $\Rightarrow$ & 3.98 & $\nabla$ \\
\hline Thailand & 61 & 4.56 & 4.63 & $\Rightarrow$ & 4.38 & $\nabla$ \\
\hline Chile 에 & 83 & 4.24 & 4.68 & $\Rightarrow$ & 4.78 & $\Rightarrow$ \\
\hline Korea Republic 이 & 99 & 3.96 & 5.25 & $\pi$ & 4.85 & $\Rightarrow$ \\
\hline Russian Federation 연 & 102 & 3.87 & 4.46 & $\Rightarrow$ & 4.19 & $\Rightarrow$ \\
\hline Vietnam & 105 & 3.83 & 4.11 & $\Rightarrow$ & 3.67 & $\nabla$ \\
\hline New Guinea & 134 & 3.14 & 2.61 & $\nabla$ & 2.6 & $\nabla$ \\
\hline Brunei Darussalam & 138 & 3.01 & 3.61 & $\nabla$ & 3.19 & $\nabla$ \\
\hline
\end{tabular}

Source: Compilation, based on the World Economic Forum (2015)

Similarly, the disconnection with government agencies has been a key factor in developing the academic niche and local, regional and national organizations that look after the resource on which the activity depends.

\section{Conclusions}

It is considered of the utmost importance that those responsible for current and potential tourist areas know the problems caused by tourism activity, with the aim of correcting them and avoiding them as much as possible, for which it is necessary to work on the basis of proper planning, introducing preventive and corrective measures.

In this sense, this article represents a first approximation to how APEC tourism managers should prioritize the disadvantages of mass tourism, the importance of maintaining a tripartite balance of development and the need to look for other options in tourism planning, management and development.

Most APEC countries have taken steps in the last decade to improve environmental management and reduce ecological costs caused by the rapid growth of tourism. However, at the regional level, joint environmental discussion and competitiveness of action are in their infancy.

Organizations such as the UNWTO have posed challenges in the search for sustainable tourism, and yet these have not been sufficient to mitigate the environmental detriment and its risk. As a result,Sustainable Tourism Observatories have been typified, with which we seek to build indicator programs and monitor the way in which sustainable tourism is developed These observatories are the new step of the UNWTO to mitigate the increasing pollution of tourism where sustainability, limits and carrying capacity become their own.

In the present year of 2017 the focus has been on care, education and sustainable development. However, there are many challenges and objectives. What is certain is that the tourist evolution guides a development towards 
these parameters, where it is necessary to work locally, regionally and globally to mitigate them, even if this reflects the need to stop being part of organizations such as the UNWTO.

Analyzing some WTO members and non-members, it becomes clear that the most efficient way to continue along the path of sustainability is to favour non-governmental and academic organizations, which result in more sustainable travel, with less environmental impact and which act as an educational factor for the generations doing tourism.

\section{References}

Alday, M. Á., \& Ara, A. F. V. (2012). Impacto económico del ocio en el siglo XXI. Arbor, 188(754), 351-363. https://doi.org/10.3989/arbor.2012.754n2008

APEC Secretariat. (2002). Public/private partnerships for sustainable tourism: delivering a sustainability strategy for tourism destinations. Recuperado de. Retrieved from http://sustain.pata.org/wp-content/uploads/2014/12/PublicPrivatePartners_APEC.pdf

Arias, F. (2011). Desarrollo sostenible y sus indicadores. Sociedad y Economía, (11), 200-229.

Cardoso, F. (2007). Sustentabilidad y planeación. Revista Periplo Sustentable, (11). Universidad Autónoma del Estado de México. Recuperado de. Retrieved from http://www.uaemex.mx/plin/psus/rev11/1a.htm

Chávez, C. L. N., Zamora, A. I., \& Torres, M. C. (2015). Análisis de Escalamiento Multidimensional del turismo de los países que conforman la APEC. Turismo y Sociedad, (16), 17-30. https://doi.org/10.18601/01207555.n16.02

Coccossis, H., \& Mexa, A. (2017). The challenge of tourism carrying capacity assessment: theory and practice. Routledge.

Edgell Sr, D. L. (2016). Managing sustainable tourism: A legacy for the future. Routledge.

Elliot, S. M. (2014). Turismo y medio ambiente: dos realidades sinérgicas. Papers de Turisme, (3).

García, J. (2013). Alianza del Pacífico.¿ Hacia dónde vamos?. Agenda Internacional, 20(31), 43-54.

Hall, C. M. (2013). Green growth and tourism for a sustainable future: "We just need to put the right policies in place", or, the lunatics have taken over the asylum. Presented at International Critical Tourism Studies. Recuperado de. Retrieved from http://canterbury-nz.academia.edu/CMichaelHall

Ibáñes, R. M. (2016). Competitividad turística en economías APEC. PORTES, Revista Mexicana de Estudios Sobre la Cuenca del Pacífico, 9(17), 33-73.

Korstanje, M. (2008). ¿Qué es el Turismo: una discusión teórica? Pensando Turismo. Recuperado de. Retrieved from http://s3.amazonaws.com/academia.edu.documents/39412099/Que_es_el_turismo.pdf?AWSAccessKeyId= AKIAIWOWYYGZ2Y53UL3A\&Expires=1485478172\&Signature=17MAtv9yvo0Wucq80 $\mathrm{cmt} 0 \mathrm{ktpOIY \% 3}$ D\&response-content-disposition=inline\%3B\%20filename\%3DQue_es_el_turismo.pdf

Manning, E. W. (2004). (Principal author and editor) Indicators of Sustainable Development for Tourism Destinations: A Guidebook. Madrid: World Tourism Organization.

Manning, T. (1999). Indicators of tourism sustainability. Tourism management, 20, 179-182.

McIntosh, R. W., \& Shaghikant, G. (1987). Turismo, planeación, administración y perspectivas. México: Limusa.

OMT, B. (2016). Panorama OMT del turismo: 2016, Organización Mundial de Turismo. [En línea], España. Disponible en: http://mkt.unwto.org/highlights

Pérez, R. M. I. (2015). Competitividad turística en economías del APEC. PORTES, Revista mexicana de estudios sobre la Cuenca del Pacifico.

Quiroga, M. R. (2007). Indicadores ambientales y de desarrollo sostenible: avances y perspectivas para América Latina y el Caribe. CEPAL.

Vilches, A., \& Gil, P. (2003). Construyamos un futuro sostenible. Diálogos de supervivencia. Madrid: Cambridge University Press.

WEF, F. E. M. (2017). The Global Competitiveness Report 2016-2017. World Economic Forum.

World Economic Forum. (2015). The Global Competitiveness Report 2014-2015. 
WTTO (1993). Indicators for the sustainable management of tourism: Report of the International Working Group on Indicators of Sustainable Tourism to the Environment Committee World Tourism Organization.

WTTO. (2016). Panorama OMT del turismo: 2016, Organización Mundial de Turismo. [En línea], España. Disponible en: http://mkt.unwto.org/highlights

\section{Note}

Note 1. http://www.adriaticgreenet.org/icareforeurope/wp-content/uploads/2013/11/Indicators-of-Sustainable -Development-for-Tourism-Destinations-A-Guide-Book-by-UNWTO.pdf

\section{Copyrights}

Copyright for this article is retained by the author(s), with first publication rights granted to the journal.

This is an open-access article distributed under the terms and conditions of the Creative Commons Attribution license (http://creativecommons.org/licenses/by/4.0/). 